\title{
Simultaneous Detection of Nine Grapevine Viruses by Multiplex Reverse Transcription-Polymerase Chain Reaction with Coamplification of a Plant RNA as Internal Control
}

\author{
Giorgio Gambino and Ivana Gribaudo
}

Plant Virology Institute CNR (IVV), Grugliasco Unit. Via L. da Vinci 44, I-10095, Grugliasco-TO, Italy. Accepted for publication 7 June 2006.

\begin{abstract}
Gambino, G., and Gribaudo, I. 2006. Simultaneous detection of nine grapevine viruses by multiplex reverse transcription-polymerase chain reaction with coamplification of a plant RNA as internal control. Phytopathology 96:1223-1229.

A multiplex reverse transcription-polymerase chain reaction (mRTPCR) was developed for simultaneous detection of nine grapevine viruses: Arabis mosaic virus, Grapevine fanleaf virus, Grapevine virus A, Grapevine virus B, Rupestris stem pitting-associated virus, Grapevine fleck virus, Grapevine leafroll-associated virus-1, -2, and -3, in combination with a plant RNA internal control used as an indicator of the effectiveness of RNA extraction and RT-PCR. Primers were designed from

quencing PCR products. Two plant total RNA extraction methods (silica capture and modified RNeasy method) and two RT-PCR systems (onestep and two-step) were evaluated to develop a reliable protocol for mRTPCR. One to nine fragments specific for the viruses were simultaneously amplified from infected samples and identified by their specific molecular sizes in agarose gel electrophoresis. In the two-step mRT-PCR, the detection limits were $10^{-3}$ or $10^{-4}$ extract dilutions, depending on the virus. Leaves, phloem from dormant cuttings, and in vitro plantlets from 103 naturally infected and healthy grapevines were analyzed. The mRT-PCR provided a reliable and rapid method for detecting grapevine viruses from a large number of samples.
\end{abstract} conserved regions of each virus and their specificity was confirmed by se-

Grapevines (Vitis spp.) are affected by many viral diseases; the most harmful and widespread ones are fanleaf degeneration, leafroll, rugose wood, and fleck. The soilborne nepovirus Grapevine fanleaf virus (GFLV) causes fanleaf degeneration (25). Arabis mosaic virus (ArMV) is a European nepovirus involved in the aetiology of grapevine degeneration (25). At least nine serologically distinct viruses, Grapevine leafroll-associated virus$1,-2,-3,-4,-5,-6,-7,-8$, and $-9(\mathrm{GLRaVs})$, have been associated with leafroll disease $(2,26)$. Rugose wood can be divided into four distinct disorders based on symptoms expressed on specific Vitis indicators: Kober stem grooving, LN 33 stem grooving, Corky bark, and Rupestris stem pitting. Grapevine virus $A$ (GVA) and Grapevine virus $B(\mathrm{GVB})$ are thought to be involved in Kober stem grooving disease (9) and Corky bark disease (6), respectively. According to several authors, Rupestris stem pittingassociated virus (RSPaV) is associated with Rupestris stem pitting disease (27) and a close association between the presence of $\mathrm{RSPaV}$ and symptoms of vein necrosis has been recently observed (7). Grapevine fleck virus (GFkV) is latent in Vitis vinifera but induces specific foliar symptoms in the indicator V. rupestris (36).

The most important strategy to control viral diseases in grapes is preventive and consists of planting virus-free vines during vineyard establishment. Propagation material with optimal sanitary status is produced through certification schemes, which use reliable techniques for detecting viruses associated with most common and harmful diseases. Grapevine virus detection is based on bioassays, serological tests (enzyme-linked immunosorbent assay [ELISA]), and more recently, reverse transcription-polymerase

Corresponding author: G. Gambino; E-mail address: g.gambino@ivv.cnr.it

DOI: 10.1094/PHYTO-96-1223

(c) 2006 The American Phytopathological Society
Additional keywords: diagnosis, multiple detection, Vitis. chain reaction (RT-PCR). Bioassays are used widely but are timeconsuming. Low virus concentrations in host tissues do not always permit satisfactory and reproducible detection by ELISA $(22,30)$. In recent years, PCR has gained popularity due to its higher sensitivity over bioassays and ELISA. It is particularly useful if antisera for ELISA are not available or not suitable. However, the reliability of RT-PCR is limited by the presence, in plant extracts, of inhibitors of the reverse transcriptase and/or polymerase, resulting generally in decreased sensitivity. Different procedures have been developed to eliminate these inhibitors and shorten the extraction protocols $(24,33,39)$. Multiplex RT-PCR (mRT-PCR) protocols have been developed for detection of several viruses in a single reaction, thus providing quick, reliable and cost-effective routine diagnosis. Simultaneous amplification by mRT-PCR of RNAs from two to five plant viruses has been reviewed by López et al. (23). There are only a few examples in which more than five plant viruses were amplified in a single mRT-PCR, probably because of the technical difficulties in designing a reaction involving many compatible primers $(5,19$, $34,38)$.

In this work, we describe the simultaneous detection of nine grapevine-infecting viruses: ArMV, GFLV, GVA, GVB, RSPaV, GFkV, GLRaV-1, GLRaV-2, and GLRaV-3. Primers for Vitis 18S rRNA were used as indicators of RNA quality and RT-PCR effectiveness. We compared two RNA extraction protocols that could be used for reliable mRT-PCR in different tissues such as in vitro plantlets, leaves from actively growing field vines, and phloem from dormant canes. The sensitivity of different RT-PCR procedures was compared.

\section{MATERIALS AND METHODS}

Plant material. All samples used for protocol development were obtained from naturally infected grapevines with single or 
multiple infections by ArMV, GFLV, GVA, GVB, RSPaV, GFkV, GLRaV-1, GLRaV-2, and GLRaV-3. They were identified by serological reactions (ELISA) and/or single RT-PCR (sRT-PCR). As infected control for mRT-PCR optimization, a sample was produced by mixing leaf material from six infected grapevines: $V$. vinifera cultivars Bruciapagliaio infected with GVA, GLRaV-1, and GLRaV-3; Moscato infected with RSPaV and GFkV; Albarossa infected with GVB; Vermentino infected with GLRaV2; Pinot Noir infected with ArMV; and the rootstock Kober 5BB $(V$. berlandieri $\times V$. riparia) infected with GFLV. Healthy plants of Grignolino regenerated from somatic embryos (14) were used as uninfected control. Infected and uninfected control plants were cultivated in vitro and micropropagated by repetitively subculturing apical cuttings on a modified Murashige and Skoog (31) medium with half-strength mineral salts and without plant growth regulators.

Samples from 103 field-grown plants and in vitro plantlets (69 from north-western Italy, 12 from north-eastern Italy, and 22 from southern Italy) belonging to 38 different grapevine cultivars were assayed by ELISA, sRT-PCR, and mRT-PCR to evaluate the effectiveness and specificity of the developed protocol. The grapevine plants were in part assayed in the framework of sanitary surveys and in part selected on the basis of their known infectious status. Different tissues were sampled: in vitro plantlets (37 samples), basal leaves collected from July to September (16 samples), and phloem scraped from mature canes collected during winter pruning (50 samples). Considering the possible uneven distribution of viruses within a given plant $(11,22)$, samples from at least two different shoots or canes of the same plant were mixed. For each plant, samples for ELISA and RT-PCR were collected at the same time and from the same sources.

ELISA. ELISA was done as previously described (14) for detection of GFLV, GVA, GVB, GFkV, GLRaV-1, GLRaV-2, and GLRaV-3. Polyclonal antisera and monoclonal antibodies were purchased from Agritest (Valenzano, Italy).

RNA extraction. Total RNA was extracted from $200 \mathrm{mg}$ of different grapevine tissues. Two easy and rapid methods were evaluated to select a reliable procedure for RNA extraction: silica capture and modified RNeasy method. For each tissue (leaves, canes, and plantlets), 10 samples (in three independent extractions) were processed by both methods. All samples were immediately frozen and homogenized in liquid nitrogen. The silica capture protocol was carried out as described by Rott and Jelkmann (33). For the RNeasy method (RNeasy Plant Mini Kit; Qiagen, Hilden, Germany), we used the protocol of MacKenzie et al. (24) with modifications. Extraction buffer (4 M guanidine isothiocyanate, $0.2 \mathrm{M}$ sodium acetate [pH 5.0], $25 \mathrm{mM}$ EDTA, $2.5 \%$ PVP-40, $2 \%$ sarkosyl, and 1\% 2-mercaptoethanol added just before use) was added to the homogenized sample and, after one extraction with chloroform/isoamyl alcohol (24:1, vol/vol), approximately $650 \mu \mathrm{l}$ of extraction buffer was transferred to a QIAShreder column and centrifuged. In the successive steps, the extraction was carried out as described in the manufacturer's handbook.

RNA purity and concentration were assessed by determining the spectrophotometric absorbance of the samples (in $10 \mathrm{mM}$ Tris- $\mathrm{HCl}$ buffer, $\mathrm{pH} 7.5$ ) at 230, 260, and $280 \mathrm{~nm}$ and ratios of $A_{260} / A_{280}$ and $A_{260} / A_{230}$. RNA quality was evaluated by $1 \%$ formaldehyde-agarose gel electrophoresis and visualization by UVlight after staining with ethidium bromide.

Virus-specific primers. Several primer sets for virus detection and for Vitis 18S rRNA, used as an indicator of RT-PCR effectiveness, were evaluated. Previously published primers for ArMV (24,32), GFLV (10,13,24), GVA (14,16), GVB (29), RSPaV $(27,32), \operatorname{GFkV}(37), \operatorname{GLRaV}-1$ (14,17), GLRaV-2 (1,4), GLRaV-3 $(14,24,29)$, and 18S rRNA (14) were tested. In addition, new primers were designed on conserved regions of each virus and the RNA internal control to allow amplification of DNA fragments of different sizes. When several sequences of virus isolates/strains and Vitis 18S rRNA were available in GenBank of the National Center for Biotechnology Information (NCBI), highly conserved regions were determined from sequence alignments using ClustalW 1.82 (8) (ClustalW provided online by the European Bioinformatics Institute [EMBL-EBI]). Primers were designed using the software Primer 3 (35) (Primer 3 software provided online by Steve Rozen and Whitehead Institute for Biomedical Research). To ensure that the primer sequence was unique for a given virus, similarity to other known sequences was checked using BLAST (BLAST provided online by NCBI). Possible primer-primer interactions were determined by the software AutoDimer (40) (AutoDimer provided online by the National Institute of Standards and Technology [NIST]). Preliminary tests were done combining the primers in a multiplex reaction. The chosen primer sequences, their location within the viral genome, and the expected amplified fragment size are shown in Table 1.

SRT-PCR. The designed primer sets were tested separately in a two-step sRT-PCR prior to multiplex analysis. First-strand cDNA synthesis was performed using $1 \mu \mathrm{g}$ of total RNA treated with DNase, following manufacturer's instructions (Invitrogen Life Technologies, Carlsbad, CA), 200 units of recombinant Moloney Murine Leukemia Virus (MMLV) reverse transcriptase (Invitrogen Life Technologies), 100 units of RNase inhibitor (RNase out, Invitrogen Life Technologies), $0.5 \mathrm{mM}$ dNTPs, and $2.5 \mu \mathrm{M}$ random nonamers (Sigma-Aldrich, St. Louis, MO). The mix for reverse transcriptase $(20 \mu \mathrm{l})$ was incubated for $50 \mathrm{~min}$ at $37^{\circ} \mathrm{C}$. The PCR mix $(25 \mu \mathrm{l})$ contained $2 \mu \mathrm{l}$ of cDNA ( $10 \%$ of the firststrand reaction, corresponding to about $100 \mathrm{ng}$ of total RNA), $1 \times$ (2.5 $\mu \mathrm{l})$ PCR buffer (Invitrogen Life Technologies), $0.2 \mathrm{mM}$ dNTPs, $0.25 \mu \mathrm{M}$ each primer, $1.5 \mathrm{mM} \mathrm{MgCl}_{2}$, and 0.5 units of Taq polymerase (PlatinumTaq polymerase, Invitrogen Life Technologies). Cycling conditions for all primer pairs consisted of initial denaturation at $94^{\circ} \mathrm{C}$ for 4 min followed by 35 cycles at $94^{\circ} \mathrm{C}$ for $30 \mathrm{~s}, 56^{\circ} \mathrm{C}$ for $45 \mathrm{~s}$, and $72^{\circ} \mathrm{C}$ for $1 \mathrm{~min}$. Reaction products were analyzed by electrophoresis on $2.5 \%$ agarose gels buffered in TBE (45 mM Tris-borate, $1 \mathrm{mM}$ EDTA) and visualized by UV light after staining with ethidium bromide.

mRT-PCR. Two mRT-PCR methods were evaluated: two-step and one-step. The mRT-PCR was optimized by varying reaction components and cycling conditions one at a time according to Henegariu et al. (18). Annealing temperature was increased from 48 to $56^{\circ} \mathrm{C}$ by single incremental temperature units. At the selected annealing temperature, the amplifications were carried out for different extension times $(60,90,120,150$, and $180 \mathrm{~s})$ and at different primer concentrations (from 0.08 to $2 \mu \mathrm{M}$ ), $\mathrm{MgCl}_{2}$ $(1.5,3,4.5,6$, and $8 \mathrm{mM})$, dNTPs $(0.2,0.3,0.4$, and $0.5 \mathrm{mM})$, PCR buffer $(1,1.5,2,2.5$, and $3 \times)$, and Taq polymerase $(0.5,1$, $1.5,2,2.5$, and 3 units).

Two-step mRT-PCR was performed with $2 \mu \mathrm{l}$ of reverse-transcribed cDNA (about $100 \mathrm{ng}$ of total RNA) in a $25-\mu$ l reaction mixture consisting of $1.5 \times(3.75 \mu \mathrm{l})$ PCR buffer (Invitrogen Life Technologies), $3 \mathrm{mM} \mathrm{MgCl} 2,0.3 \mathrm{mM}$ dNTPs, and 1.5 units of Taq polymerase (PlatinumTaq polymerase). Final primer concentrations were $0.08 \mu \mathrm{M} 18 \mathrm{~S}$ rRNA, $0.8 \mu \mathrm{M}$ GLRaV-2, $0.16 \mu \mathrm{M}$ GVB, $0.8 \mu \mathrm{M}$ ArMV, 0.6 $\mu \mathrm{M}$ GLRaV-3, 0.6 $\mu \mathrm{M}$ GVA, $0.3 \mu \mathrm{M}$ GLRaV-1, $0.4 \mu \mathrm{M}$ GFkV, $0.6 \mu \mathrm{M}$ RSPaV, and 0.6 $\mu \mathrm{M}$ GFLV. Cycling conditions were as follows: initial denaturation at $94^{\circ} \mathrm{C}$ for $4 \mathrm{~min}$ followed by 35 cycles at $94^{\circ} \mathrm{C}$ for $30 \mathrm{~s}, 50^{\circ} \mathrm{C}$ for $1 \mathrm{~min}$, and $72^{\circ} \mathrm{C}$ for $1 \mathrm{~min}$ and $30 \mathrm{~s}$. Reaction products were analyzed as reported above.

One-step mRT-PCR was carried out with the OneStep RT-PCR Kit (Qiagen) in a 25- $\mu$ l reaction mixture consisting of $100 \mathrm{ng}$ of total RNA treated with DNase following manufacturer's instructions (Invitrogen Life Technologies,), 1× (5 $\mu \mathrm{l})$ RT-PCR buffer (Qiagen), $0.4 \mathrm{mM}$ dNTPs, and $2 \mu \mathrm{l}$ of OneStep RT-PCR enzyme mix (Omniscript Reverse Transcriptase, Sensiscript Reverse Transcriptase and HotStar Taq DNA Polymerase, Qiagen). Final 
primer concentrations were as follows: $0.08 \mu \mathrm{M}$ 18S rRNA, 1.8 $\mu \mathrm{M}$ GLRaV-2, 0.2 $\mu \mathrm{M}$ GVB, $2 \mu \mathrm{M}$ ArMV, 1.2 $\mu \mathrm{M}$ GLRaV-3, $0.2 \mu \mathrm{M}$ GVA, $0.3 \mu \mathrm{M}$ GLRaV-1, $0.2 \mu \mathrm{M}$ GFkV, $0.8 \mu \mathrm{M}$ RSPaV, and $1.6 \mu \mathrm{M}$ GFLV. Reverse transcription was carried out for $50 \mathrm{~min}$ at $47^{\circ} \mathrm{C}$. Subsequent cycling conditions were the same used for the two-step mRT-PCR. Reaction products were analyzed as reported above. To ensure the absence of nonspecific amplification, each RT-PCR run included water as negative control and one healthy plant sample.

Sensitivity and specificity of mRT-PCR. To determine the detection limits of mRT-PCR and sRT-PCR, total RNA extracted from the positive control was diluted serially 10 -fold (from $10^{\circ}$ to $10^{-6}$ ) in total RNA extracted from healthy grapevines and used in sRT-PCR, one-step mRT-PCR, and two-step mRT-PCR. Reaction products were analyzed as reported previously. To confirm the identity of the amplified fragments, RT-PCR products for each virus and internal control were purified by ExoSAP-IT (GE Healthcare Bio-Sciences, Uppsala, Sweden) following manufacturer's instructions, and sequenced using specific primer pairs (Table 1) in both orientations (sequencing performed by Bio Molecular Research, University of Padova, Italy). The sequences obtained were compared with the sequences published in GenBank NCBI.

\section{RESULTS}

RNA extraction. Both the silica capture and the modified RNeasy method allowed rapid extraction of total RNA from different grapevine tissues, but resulted in different RNA qualities
(Table 2). RNA prepared by silica gel was low in purity: the average ratios of spectrophotometric absorbance $A_{260} / A_{280}$ and $A_{260} / A_{230}$ indicated protein contamination and large amounts of impurities caused by co-precipitation of aromatic compounds and polysaccharide complexes. Degradation of $28 \mathrm{~S}$ and 18S rRNA showed that the quality of extracted RNA was poor (Fig. 1).

RNA prepared with the modified RNeasy method was relatively free of protein, polysaccharide, and phenolic compounds as indicated by the $A_{260} / A_{280}$ and $A_{260} / A_{230}$ ratios (Table 2 ). The intact $28 \mathrm{~S}$ and $18 \mathrm{~S}$ rRNA bands on formaldehyde-agarose gel (Fig. 1) indicated that little or no RNA degradation occurred during extraction. The standard RNeasy method, following manufacturer's instructions (Qiagen), gave lower yields of poor-quality RNA or was unable to extract RNA from leaves of field-grown plants and from phloem of mature canes (data not shown). An additional extraction step with chloroform/isoamyl alcohol removed contaminants and increased the binding capacity of RNeasy columns.

The higher RNA yields with silica capture (Table 2) compared with that of RNeasy are due to the impurities extracted. The average RNA yields with the modified RNeasy method (Table 2) were adequate for testing samples by RT-PCR. Therefore, this protocol was used throughout the mRT-PCR experiments.

Optimization of mRT-PCR. Previously published primer sets for the detection of seven grapevine viruses (ArMV, GFLV, RSPaV, GFkV, GLRaV-1, GLRaV-2, and GLRaV-3) and for RNA internal control (18S rRNA) were not adequate for the mRT-PCR. Published primers for GFLV (24), GLRaV-1 (14), GLRaV-3 (14, $24,29)$, and $\operatorname{RSPaV}(27,32)$ amplified products with similar sizes

TABLE 1. Primer sequences, reverse transcription-polymerase chain reaction product size, and sequence location within the viral genome

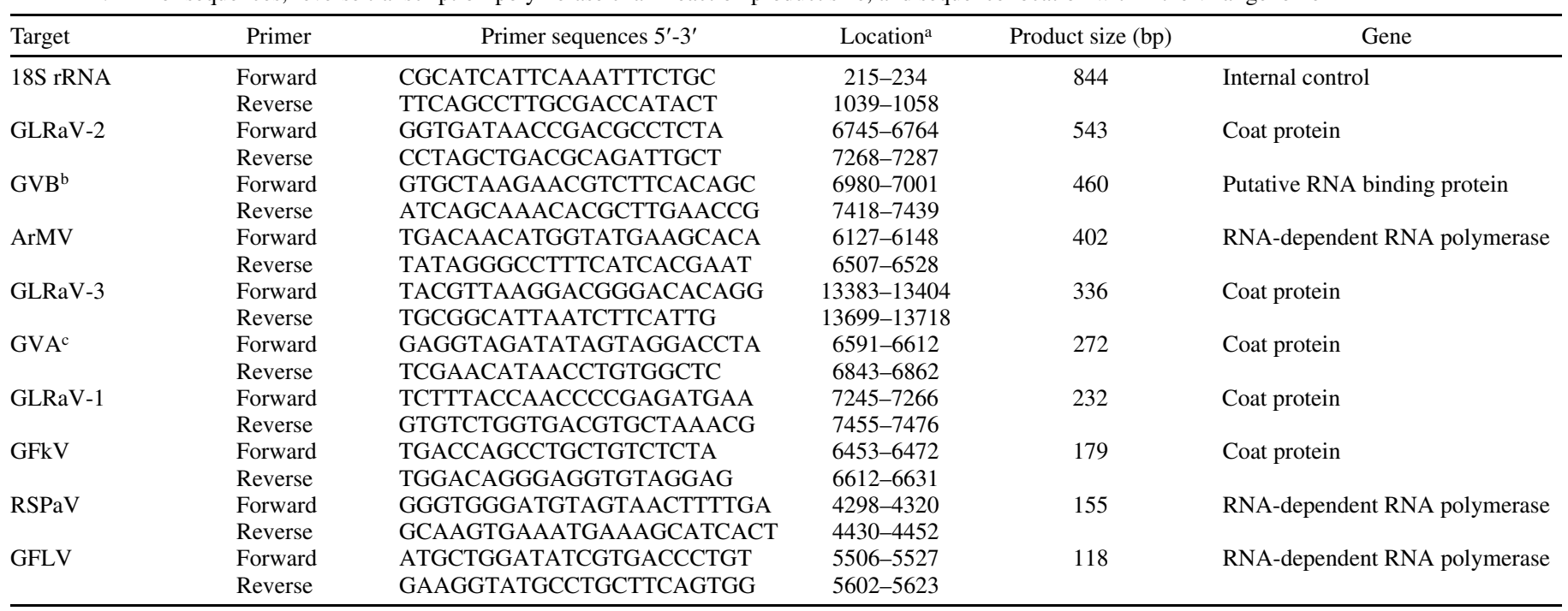

${ }^{a}$ The reference accession numbers (NCBI) for determining the primer positions are AF321266 for 18S rRNA, Y14131 for Grapevine leafroll-associated virus-2 (GLRaV-2), NC_003602 for Grapevine virus B (GVB), NC_006057 for Arabis mosaic virus (ArMV), NC_004667 for GLRaV-3, NC_003604 for Grapevine virus A (GVA), AF195822 for GLRaV-1, NC_003347 for Grapevine fleck virus (GFkV), NC_001948 for Rupestris stem pitting-associated virus (RSPaV), and NC_003615 for Grapevine fanleaf virus (GFLV).

b Primers designed by Minafra and Hadidi (29).

${ }^{c}$ Primers designed by Goszczynski and Jooste (16).

TABLE 2. Purity and yield (mean \pm standard deviation) of total RNA extracted by silica capture and the modified RNeasy method from different grapevine tissues $^{\mathrm{a}}$

\begin{tabular}{|c|c|c|c|c|c|c|}
\hline \multirow[b]{2}{*}{ Tissues } & \multicolumn{2}{|c|}{$A_{260} / A_{280}$} & \multicolumn{2}{|c|}{$A_{260} / A_{230}$} & \multicolumn{2}{|c|}{ RNA yield $(\mu \mathrm{g} / 100 \mathrm{mg})$} \\
\hline & Silica capture & RNeasy & Silica capture & RNeasy & Silica capture & RNeasy \\
\hline In vitro plantlets & $1.41 \pm 0.13$ & $1.94 \pm 0.11$ & $0.21 \pm 0.04$ & $2.11 \pm 0.26$ & $12.55 \pm 3.05$ & $9.59 \pm 3.11$ \\
\hline Leaves from field-grown plants & $1.62 \pm 0.16$ & $1.86 \pm 0.11$ & $0.18 \pm 0.06$ & $1.72 \pm 0.13$ & $14.45 \pm 4.30$ & $5.88 \pm 2.13$ \\
\hline
\end{tabular}

a Purity was evaluated as absorption ratios at different UV wavelengths $\left(A_{260} / A_{280}\right.$ and $\left.A_{260} / A_{230}\right)$. For each tissue, 10 samples in three independent RNA extractions were measured. 
(from 300 to $350 \mathrm{bp}$ ) that were not separable in agarose gel. Primers for GLRaV-1 (17), GFkV (37), and ArMV (24) produced extra bands in the multiplex reaction, whereas primers for GFLV $(10,13)$, GLRaV-2 (1,4), ArMV (32), and 18S rRNA (14) gave undetectable fragments in the mRT-PCR (data not shown). New primer pairs for the cited viruses, as well as primers for GVA (16) and GVB (29) that did not show primer-primer interactions, were tested separately by SRT-PCR to confirm their specificity and to assess the size of the RT-PCR products. Amplified products of expected sizes (Table 1) were observed only from infected samples and not from RNA extracted from healthy plants (Fig. 2).

The mRT-PCR conditions were optimized as described above for both one-step and two-step systems. Optimal primer concentrations for each virus were essential, as well as decreasing the annealing temperature at $50^{\circ} \mathrm{C}$ and increasing extension time, PCR buffer, dNTPs, $\mathrm{MgCl}_{2}$, and Taq DNA polymerase concentrations above those used in sRT-PCR.

In both assays, only mRT-PCR products of expected size were obtained from the positive control and from grapevines infected with different combinations of viruses without interference (Fig. 2 ). No amplification products were obtained from the negative control (water), and a fragment of the expected size was consistently amplified from the internal control (18S rRNA), irrespective of infected or healthy plants (Figs. 3 and 4).

Sensitivity and specificity of mRT-PCR. Total RNA extracted from the positive control was serially diluted in RNA extracted from healthy plants and used for RT-PCR. The detection limits of sRT-PCR and one-step and two-step mRT-PCR are shown in Figure 3. Two-step mRT-PCR was 100 times more sensitive than the one-step system for GVA, GLRaV-3, and ArMV, and 10 times for all other viruses (Fig. 3). In sRT-PCR, these limits ranged from $10^{-4}$ (ArMV, GVB, RSPaV, GLRaV-1, GLRaV-2, and GLRaV-3) to $10^{-5}$ (GFLV, GVA, and GFkV). sRT-PCR was 10 times more sensitive than two-step mRT-PCR with exceptions for GLRaV-1 and RSPaV, which were amplified with the same efficiency. The specific RT-PCR product of the internal control was detected in all dilutions for multiplex assays without marked difference in band intensity on the gel, because diluting RNA of the positive control in RNA of healthy grapevines lowered the concentrations of virus templates, but not of the 18S rRNA template.

Sequence comparison of RT-PCR products of all viruses and RNA internal control with the published sequences in GenBank (NCBI) confirmed their respective origin, showing the following nucleotide identities to the corresponding region: Vitis $18 \mathrm{~S}$ rRNA, 100\%; ArMV, 94\%; GFLV, 95 to 98\%; GVA, 88 to $90 \%$; GVB, 84 to $89 \%$; RSPaV, 91 to $95 \%$; GFkV, 95\%; GLRaV-1, 96\%; GLRaV-2, 89 to $99 \%$; and GLRaV-3, 90 to $99 \%$.

In order to confirm the effectiveness of mRT-PCR, 103 grapevine samples from three areas in Italy were assayed by ELISA and RT-PCR (Table 3; Fig. 4). For these analyses, the more sensitive two-step mRT-PCR was adopted instead of the one-step mRTPCR. Two-step mRT-PCR was efficient in detecting nine viruses under study regardless of the plant tissue (in vitro plants, leaves, or phloem scraped from mature canes). In some cases, bands with

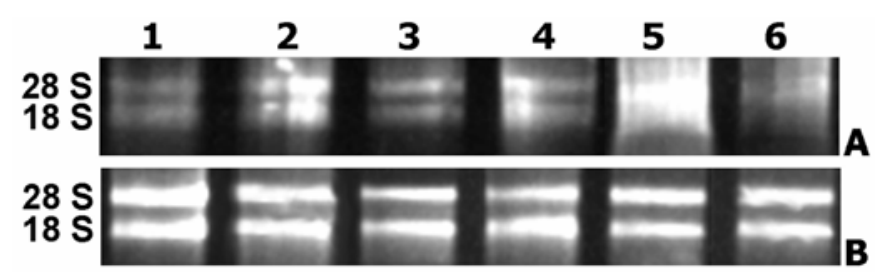

Fig. 1. RNA extracted from micropropagated plantlets grown in vitro (lanes 1 and 2), basal leaves from field-grown grapevines (lanes 3 and 4), and phloem scraped from mature canes (lanes 5 and 6 ) by $\mathbf{A}$, silica capture and $\mathbf{B}$, modified RNeasy method. Total RNA was stained by ethidium bromide on $1 \%$ formaldehyde-agarose gel. medium or low intensity were observed for individual PCR products; nevertheless, all fragments were clearly identified and assigned to the respective viruses (Fig. 4). In 8 of 103 grapevine samples, PCR methods allowed the detection of some viruses that were not detectable by ELISA; these eight samples were all from vines that were mixed infected. For all plants and all viruses under study, no discrepancy was observed between results of sRTPCR and mRT-PCR (Table 3).

\section{DISCUSSION}

This paper describes an mRT-PCR assay for the simultaneous detection of nine grapevine viruses and coamplification of $18 \mathrm{~S}$ rRNA as internal control. Simultaneous detection of grapevine viruses was previously reported but on a smaller scale. Minafra and Hadidi (29), La Notte et al. (21), and Nassuth et al. (32) used a multiplex procedure to detect two or three grapevine viruses. Dovas and Katis (11) used degenerate dI-substituted primers for the generic detection of Vitivirus, Foveavirus, and Closterovirus in the same reaction tube. More recently, Faggioli and La Starza (12) reported the application of one-step mRT-PCR for the detection of eight viruses in a sanitary selection program. To our knowledge, this is the first report of an mRT-PCR protocol allowing the simultaneous detection of the most important and widespread viruses of grapevine.

The importance of an internal control for the RT-PCR assay has been described by Bariana et al. (3). An RNA control is essential for detecting false negatives due to RNA degradation or the presence of inhibitors of the reverse transcriptase and/or Taq polymerase. Nevertheless, there are only a few cases in which an RNA control was included in an mRT-PCR $(28,32,38)$.

The method of RNA extraction may affect the overall results obtained by RT-PCR. Two methods of extraction were compared with the aims of increasing the quality of grapevine extracts for use in mRT-PCR and isolating RNA year round from different tissues (leaves, phloem from mature canes, and whole in vitro plantlets). Silica capture is a quick method with moderate cost and proven efficacy for some tree tissues (33). Unfortunately, in our experience with grapevine, it did not produce extracts that could be effectively amplified. MacKenzie et al. (24) successfully extracted grapevine RNA with the RNeasy kit. Nassuth et al. (32) obtained similar results but reported problems in extraction from old tissues. In our experiments, RNA was purified efficiently from all grapevine tissues when an extraction with chloroform/isoamyl alcohol was performed before using the RNeasy kit. With this

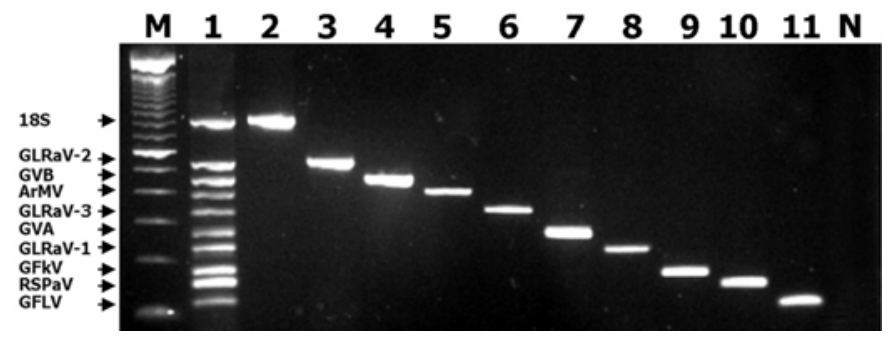

Fig. 2. Agarose gel electrophoretic analysis of DNA fragments amplified from infected and healthy grapevines by multiplex reverse transcription-polymerase chain reaction (mRT-PCR) and single RT-PCR (sRT-PCR). Details on primers are provided in Table 1. Lane 1: positive control, all primers; lane 2: healthy control, primers for 18S rRNA (844 bp); lane 3: Vermentino, primers for Grapevine leafroll-associated virus-2 (GLRaV-2; 543 bp); lane 4: Albarossa, primers for Grapevine virus B (GVB; $460 \mathrm{bp})$; lane 5: Pinot Noir, primers for Arabis mosaic virus (ArMV; 402 bp); lane 6: Bruciapagliaio, primers for GLRaV-3 (336 bp); lane 7: Bruciapagliaio, primers for Grapevine virus A (GVA; $272 \mathrm{bp}$ ); lane 8: Bruciapagliaio, primers for GLRaV-1 (232 bp); lane 9: Moscato, primers for Grapevine fleck virus (GFkV; $179 \mathrm{bp})$; lane 10: Moscato, primers for Rupestris stem pitting-associated virus (RSPaV; $155 \mathrm{bp}$ ); lane 11: Kober 5BB, primers for Grapevine fanleaf virus (GFLV; $118 \mathrm{bp}$ ); lane $\mathrm{N}$ : water with all the primers; and lane M: 100-bp DNA ladder. 
modification the protocol proved to be suitable due to its simplicity, reproducibility, and rapidity.

We examined several RT-PCR parameters to develop a reliable assay. Primer concentrations for the viruses and the internal control were optimized to determine which combination of primer concentrations gave best amplification of the expected specific fragments in several different extracts. Annealing temperature was also an important parameter for amplification efficiency. Although individual viruses and the internal control were specifically amplified at $56^{\circ} \mathrm{C}$, lowering the annealing temperature to $50^{\circ} \mathrm{C}$ was required for co-amplification in the multiplex reaction. Lowering the annealing temperature and increasing $\mathrm{MgCl}_{2}$ concentration could lead to unspecific amplification, but overcome by the concurrent amplification of an increased number of specific loci in the multiplex reaction and thus remains invisible (18).

The two systems for mRT-PCR compared in this work (onestep and two-step) were both effective in simultaneously detecting all nine viruses and 18S rRNA. The one-step system is less time- consuming than the two-step and reduces contamination risks, but the two-step system was 10 to 100 times more sensitive. This was probably due to higher susceptibility of the one-step RT-PCR to inhibitors (15). The detection limits of the two-step method were

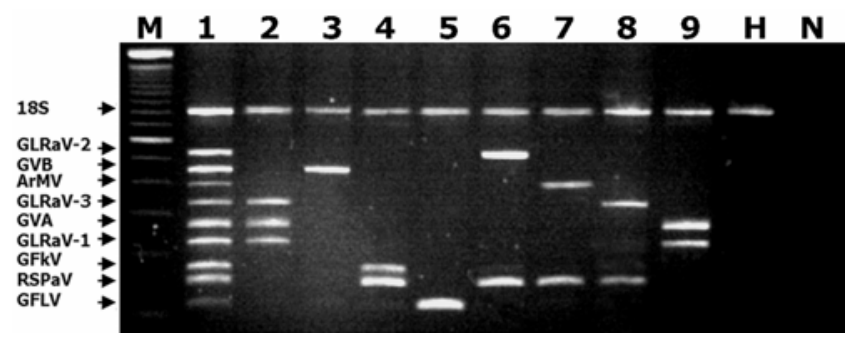

Fig. 4. Agarose gel electrophoretic analysis of DNA fragments amplified by multiplex reverse transcription-polymerase chain reaction. Lane 1, positive control; lanes 2 to 9 , naturally infected grapevines; lane $\mathrm{H}$, healthy control; lane N, water; and lane M, 100-bp DNA ladder.
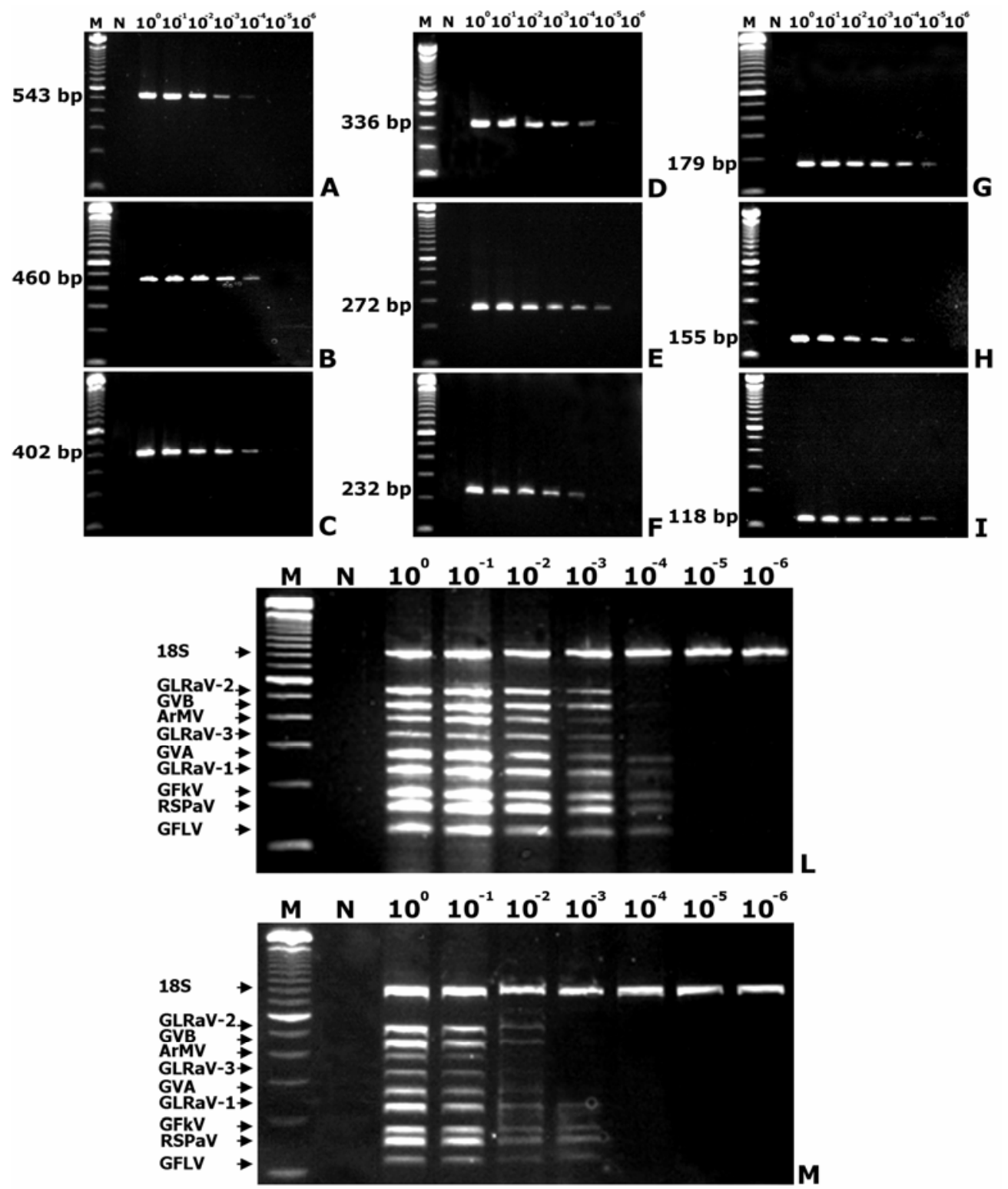

Fig. 3. Agarose gel electrophoretic analysis of DNA fragments amplified by reverse transcription-polymerase chain reaction (RT-PCR). The RNA was extracted from the positive control and serially diluted in RNA extracted from healthy plants. A, Single RT-PCR (sRT-PCR) for Grapevine leafroll-associated virus-2 (GLRaV-2); B, sRT-PCR for Grapevine virus B (GVB); C, sRT-PCR for Arabis mosaic virus (ArMV); D, sRT-PCR for GLRaV-3; E, sRT-PCR for Grapevine virus A (GVA); F, sRT-PCR for GLRaV-1; G, sRT-PCR for Grapevine fleck virus (GFkV); H, sRT-PCR for Rupestris stem pitting-associated virus (RSPaV); I, sRT-PCR for Grapevine fanleaf virus (GFLV); L, two-steps multiplex RT-PCR (mRT-PCR); and M, one-step mRT-PCR. Lanes from $10^{\circ}$ to $10^{-6}$ indicate 10 -fold serial dilutions of the positive control. Lane N, water; and lane M, 100-bp DNA ladder. 
lower than those of sRT-PCR for seven viruses because in the multiplex assay the cocktail of primers compete for all the templates rather than for one $(20,34)$. However, the level of sensitivity reported here is regarded as adequate for testing routine samples. Specific bands on the gel could be detected for all viruses up to $1: 1,000$ dilution, corresponding to $0.1 \mathrm{mg}$ of infected tissue in $100 \mathrm{mg}$ total. This allows detection of infection of one positive sample in a bulk extract of several plants, which could be useful for large-scale indexing.
One hundred and three vines of various geographical origins were analyzed by ELISA and PCR. mRT-PCR was able to reliably identify all combinations of the infecting viruses with the same efficiency as sRT-PCR. In eight grapevine samples, collected from basal leaves and phloem scraped from field material, mRT-PCR identified viruses that were not detected by ELISA. The low or variable virus titers in field material $(22,30)$ could explain the discrepancies between ELISA and mRT-PCR. We did not observe any discrepancy between ELISA and mRT-PCR in

TABLE 3. Tissues sampled, numbers of plants analyzed, and results for each virus of enzyme-linked immunosorbent assay (ELISA [E]), single reverse transcription-polymerase chain reaction (sRT-PCR [S]), and multiplex (m)RT-PCR (M) ${ }^{\mathrm{a}}$

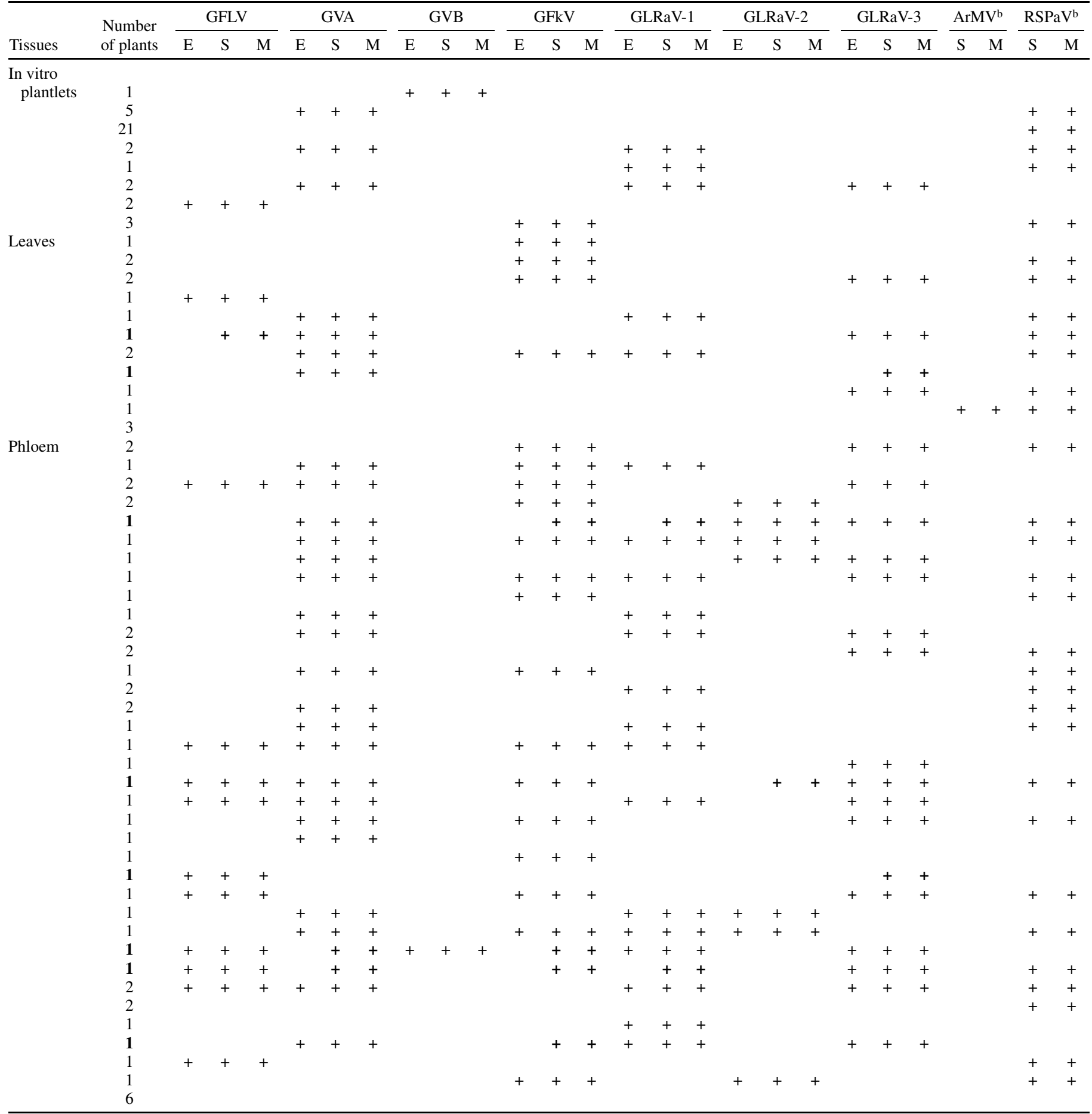

a + Indicates viruses detected by ELISA and/or RT-PCR. Samples for which viruses were detectable in RT-PCR but not in ELISA are indicated in bold. Grapevine fanleaf virus (GFLV), Grapevine virus A (GVA), Grapevine virus B (GVB), Grapevine fleck virus (GFkV), Grapevine leafroll-associated virus-1, -2, and -3, (GLRaV-1, -2, and -3), Arabis mosaic virus (ArMV), and Rupestris stem pitting-associated virus (RSPaV).

b Analyzed for ArMV and RSPaV only by sRT-PCR and mRT-PCR. 
tissue culture materials; in vitro cultures generally contain high virus titers. Some authors even suggest that it might be possible to increase the sensitivity of ELISA by micropropagating questionable field material (30).

The mRT-PCR protocol described reliable detection of ArMV, GFLV, GVA, GVB, RSPaV, GFkV, GLRaV-1, GLRaV-2, and GLRaV-3 within 1 day. This may help to save time and reduce costs, and could replace presently used techniques like ELISA or bioassays for the indexing of these viruses.

\section{ACKNOWLEDGMENTS}

We thank U. Malossini (ISMAA, San Michele all'Adige, Italy) and R. Credi (Dip. Scienze e Tecnologie Agroambientali, University of Bologna, Italy) for providing ArMV-infected samples; A. Minafra (IVVCNR, Bari, Italy) for providing GLRaV-2-infected grapevine; D. Cuozzo for her technical assistance on ELISA; and R. G. Milne for reviewing the manuscript. We also acknowledge the supply of grapevine samples from eastern Italy (U. Malossini) and southern Italy (V. Pernice, Regione Sicilia). The friendly and valuable support of F. Mannini is gratefully acknowledged.

\section{LITERATURE CITED}

1. Abou-Ghanem-Sabanadzovic, N., Sabanadzovic, S., Castellano, M. A., Boscia, D., and Martelli, G. P. 2000. Properties of a new isolate of grapevine leafroll-associated virus 2. Vitis 39:119-121.

2. Alkowni, R., Rowhani, A., Daubert, S., and Golino, D. 2004. Partial characterization of a new ampelovirus associated with grapevine leafroll disease. J. Plant Pathol. 86:123-133.

3. Bariana, H. S., Shannon, A. L., Chu, P. W. G., and Waterhouse, P. M. 1994. Detection of five seedborne legume viruses in one sensitive multiplex polymerase chain reaction test. Phytopathology 84:1201-1205.

4. Bertazzon, N., and Angelini, E. 2004. Advances in the detection of Grapevine leafroll-associated virus 2 variants. J. Plant Pathol. 86:283-290.

5. Bertolini, E., Olmos, A., Martínez, M. C., Gorris, M. T., and Cambra, M. 2001. Single-step multiplex RT-PCR for simultaneous and colourimetric detection of six RNA viruses in olive trees. J. Virol. Methods 96:33-41.

6. Boscia, D., Savino, V., Minafra, A., Namba, S., Elicio, V., Castellano, M. A., Gonsalves, D., and Martelli, G. P. 1993. Properties of a filamentous virus isolated from grapevines affected by corky bark. Arch. Virol. 130:109-120

7. Bouyahia, H., Boscia, D., Savino, V., La Notte, P., Pirolo, C., Castellano, M. A., Minafra, A., and Martelli, G. P. 2005. Grapevine rupestris stem pittingassociated virus is linked with grapevine vein necrosis. Vitis 44:133-137.

8. Chenna, R., Sugawara, H., Koike, T., Lopez, R., Gibson, T. J., Higgins, D. G., and Thompson, J. D. 2003. Multiple sequence alignment with the Clustal series of programs. Nucleic Acids Res. 31:3497-3500.

9. Chevalier, S., Greif, C., Clauzel, J.-M., Walter, B., and Fritsch, C. 1995. Use of an immunocapture polymerase chain reaction procedure for the detection of grapevine virus A in Kober stem grooving-infected grapevines. J. Phytopathol. 143:369-373.

10. Demangeat, G., Komar, V., Cornuet, P., Esmenjaud, D., and Fuchs, M. 2004. Sensitive and reliable detection of grapevine fanleaf virus in a single Xiphinema index nematode vector. J. Virol. Methods 122:79-86.

11. Dovas, C. I., and Katis, N. I. 2003. A spot multiplex nested RT-PCR for the simultaneous and generic detection of viruses involved in the aetiology of grapevine leafroll and rugose wood of grapevine. J. Virol. Methods 109:217226.

12. Faggioli, F., and La Starza, S. 2006. One-step multiplex RT-PCR for simultaneous detection of eight grapevine viruses and its application in a sanitary selection program. Pages 120-121 in: 15th ICVG Meeting, Ext. Abstr., South African Society for Enology and Viticulture (SASEV), Dennesig, South Africa.

13. Fattouch, S., M'Hirsi, S., Acheche, H., Marrakchi, M., and Marzouki, N. 2001. RNA oligoprobe capture RT-PCR, a sensitive method for the detection of Grapevine fanleaf virus in Tunisian grapevines. Plant Mol. Biol. Rep. 19:235-244.

14. Gambino, G., Bondaz, J., and Gribaudo, I. 2006. Detection and elimination of viruses in callus, somatic embryos and regenerated plantlets of grapevine. Eur. J. Plant Pathol. 114:397-404.

15. Gitton, F., Diao, A., Ducrot, O., Antoniw, J. F., Adams, M. J., and Maraite, H. 1999. A two-step multiplex RT-PCR method for simultaneous detection of soil-borne wheat mosaic virus and wheat spindle streak mosaic virus from France. Plant Pathol. 48:635-641.

16. Goszczynski, D. E., and Jooste, A. E. C. 2003. Identification of divergent variants of Grapevine virus A. Eur. J. Plant Pathol. 109:397-403.
17. Habili, N., Fazeli, C. F., and Rezaian, M. A. 1997. Identification of a cDNA clone specific to grapevine leafroll-associated virus 1, and occurrence of the virus in Australia. Plant Pathol. 46:516-522.

18. Henegariu, O., Heerema, N. A., Dlouhy, S. R., Vance, G. H., and Vogt, P. H. 1997. Multiplex PCR: Critical parameters and step-by-step protocol. Biotechniques 23:504-511.

19. Ito, T., Ieki, H., and Ozahi, K. 2002. Simultaneous detection of six citrus viroids and Apple stem grooving virus from citrus plants by multiplex reverse transcription polymerase chain reaction. J. Virol. Methods 106:235-239.

20. Jacobi, V., Bachand, G. D., Hamelin, R. C., and Castello, J. D. 1998. Development of a multiplex immunocapture RT-PCR assay for detection and differentiation of tomato and tobacco mosaic tobamoviruses. J. Virol. Methods 74:167-178.

21. La Notte, P., Minafra, A., and Saldarelli, P. 1997. A spot-PCR technique for the detection of phloem-limited grapevine viruses. J. Virol. Methods 66:103108.

22. Ling, K.-S., Zhu, H.-Y., Petrovic, N., and Gonsalves, D. 2001. Comparative effectiveness of ELISA and RT-PCR for detecting grapevine leafrollassociated closterovirus-3 in field samples. Am. J. Enol. Vitic. 52:21-27.

23. López, M. M., Bertolini, E., Olmos, A., Caruso, P., Gorris, M. T., Llop, P., Penyalver, R., and Cambra, M. 2003. Innovative tools for detection of plant pathogenic viruses and bacteria. Int. Microbiol. 6:233-243.

24. MacKenzie, D. J., Mclean, M. A., Mukerji, S., and Grenn, M. 1997. Improved RNA extraction from woody plants for the detection of viral pathogens by reverse transcription-polymerase chain reaction. Plant Dis. 81:222226.

25. Martelli, G. P. 1993. Grapevine degeneration. Pages 9-27 in: GraftTransmissible Diseases of Grapevines. Handbook for Detection and Diagnosis. G. P. Martelli, ed. FAO, Rome, Italy.

26. Martelli, G. P., Agranovsky, A. A., Bar-Joseph, M., Boscia, D., Candresse, T., Coutts, R. H. A., Dolja, V. V., Falk, B. W., Gonsalves, D., Jelkmann, W., Karasev, A. V., Minafra, A., Namba, S., Vetten, H. J., Wisler, G. C., and Yoshikawa, N. 2002. The family Closteroviridae revised. Arch. Virol. 147:2039-2044.

27. Meng, B., Johnson, R., Peressini, S., Forsline, P. L., and Gonsalves, D. 1999. Rupestris stem pitting associated virus- 1 is consistently detected in grapevines that are infected with rupestris stem pitting. Eur. J. Plant Pathol. 105:191-199.

28. Menzel, W., Jelkmann, W., and Maiss, E. 2002. Detection of four apple viruses by multiplex RT-PCR assays with coamplification of plant mRNA as internal control. J. Virol. Methods 99:81-92.

29. Minafra, A., and Hadidi, A. 1994. Sensitive detection of grapevine virus A, B, or leafroll-associated III from viruliferous mealybugs and infected tissue by cDNA amplification. J. Virol. Methods 47:175-188.

30. Monis, J., and Bestwick, R. K. 1996. Detection and localization of grapevine leafroll associated closteroviruses in greenhouse and tissue culture grown plants. Am. J. Enol. Vitic. 47:199-205.

31. Murashige, T., and Skoog, F. 1962. A revised medium for rapid growth and bio assays with tobacco tissue cultures. Physiol. Plant 15:473-497.

32. Nassuth, A., Pollari, E., Helmeczy, K., Stewart, S., and Kofalvi, S. A. 2000. Improved RNA extraction and one-tube RT-PCR assay for simultaneous detection of control plant RNA plus several viruses in plant extracts. J. Virol. Methods 90:37-49.

33. Rott, M. E., and Jelkmann, W. 2001. Characterization and detection of several filamentous viruses of cherry: Adaptation of an alternative cloning method (DOP-PCR), and modification of an RNA extraction protocol. Eur. J. Plant Pathol. 107:411-420.

34. Roy, A., Fayad, A., Barthe, G., and Brlansky, R. H. 2005. A multiplex polymerase chain reaction method for reliable, sensitive and simultaneous detection of multiple viruses in citrus trees. J. Virol. Methods 129:47-55.

35. Rozen, S., and Skaletsky, H. J. 2000. Primer3 on the WWW for general users and for biologist programmers. Pages 365-386 in: Bioinformatics Methods and Protocols: Methods in Molecular Biology. S. Krawetz and S. Misener, eds. Humana Press, Totowa, NJ.

36. Sabanadzovic, S., Abou-Ghanem, N., Castellano, M. A., Digiaro, M., and Martelli, G. P. 2000. Grapevine fleck virus-like viruses in Vitis. Arch. Virol. 145:553-565.

37. Sabanadzovic, S., Saldarelli, P., and Savino, V. 1996. Molecular diagnosis of grapevine fleck virus. Vitis 35:137-140.

38. Sánchez-Navarro, J. A., Aparicio, M. C., Herranz, M. C., Minafra, A., Myrta, A., and Pallás, V. 2005. Simultaneous detection and identification of eight stone fruit viruses by one-step RT-PCR. Eur. J. Plant Pathol. 111:77-84.

39. Staub, U., Polivka, H., and Gross, H. J. 1995. Two rapid microscale procedures for isolation of total RNA from leaves rich in polyphenols and polysaccharides: Application for sensitive detection of grapevine viroids. J. Virol. Methods 52:209-218.

40. Vallone, P. M., and Butler, J. M. 2004. AutoDimer: A screening tool for primer-dimer and hairpin structures. Biotechniques 37:226-231. 